\title{
Problem Solving Ability Of Students Mathematics In Problem Based Learning
}

\author{
Nurdiana Siregar \\ Prodi Pendidikan Guru Sekolah Dasar \\ Universitas Nahdlatul Ulama Sumatera Utara \\ Email: nurdiana884@yahoo.co.id
}

(Received: Nopember-2017; Reviewed: Nopember-2017; Accepted: November-2017; Published: Desember-2017)

(C2017 -EST Graduate Program Universitas Negeri Makassar. This is an article with open access under license CC BY-NC-4.0 (https://creativecommons.org/licenses/by-nc/4.0/ ).

\begin{abstract}
The objective of this study were to determine the increasing of students' problem solving ability and self confidence after the implementation of problem based learning and to see the interaction between gender and learning to increas problem solving ability and students' self confidence. The method kuantitaif with the design of this research was quasi-experimental with factorial design is $2 \times 2$. There were 73 students as the sample of this study containing 36 students in grade VIII-5 and 37 students in grade VIII-6. The instruments of this students were test of problem solving and self confidence scale. The data were analyzed by applying two way analysis of variance (ANOVA). The result showed that (1) The increasing of students' problem solving ability taught by using problem based learning was higher than that taught by using conventional learning (2) There was no interaction between gender and learning with increasing of students' problem solving ability.
\end{abstract}

Keywords: problem solving ability; problem based learning

\section{INTRODUCTION}

The ability is able to find of answer from problem, the first identify, the next to arrange strategy or to plan problem solving, to apply planning which was arranged and then to evaluate of the solution. National Council of Teachers of Mathematics (NCTM) emphasizes problem solving as focus central in mathematics curriculums (Wahyudin, 2008: 67). The regulation of education minister No. 22 in 2006 about the content standard stated the purpose of mathematics learning, i.e. the students have a problem solving ability.

The fact was found when pre-research gave problem to 38 students of Junior High School in Medan Prayatna that $68 \%$ students have not able to reveal information about the problem, $82 \%$ students have not understood of problems and arrange strategy, $82 \%$ students have not able to apply concepts in problem, and $87 \%$ student have not able to correct the solution. So it asserts that problem solving ability of mathematics students is low.

Many factors to increase problem solving skill, one of all is gender. It was, according to by Papalia and Ruth (2014: 337) that gender is one of the factors could influence student achievement. Ma and Kishor (Hannula et al, 2005: 23) found that Gender is an important variable to analysis correlation both of influence and achievement. Besides, Zhu (2007:189) that many factors were suggested to have contributions to gender difference in mathematical problem solving such as cognitive abilities, speed of processing information and learning styles.

Models of learning are one of the answers to solve the problems. Hudojo (2005:107) says on mathematics learning that 
mathematics materials are not explained directly, but step by step which involves student to find concepts, structures of theorem or formulas. The results of Pirnta et al (2009: 384) explaining teacher behavior such as managing classes with various activities give effect to the students' math problem solving abilities.

The problem could solve with problem based learning (PBL). In problem-based learning builds many interactions between teachers and students. Koch (in Slavin, 2008: 160) states that men interact more with teachers than women. Woolfolk (2009 : 109) says PBL has had purpose to increase problem solving skill.

Because of that, this research would discuss problem solving ability of students' mathematics in problem based learning with a purpose; 1) know increasing of skill problem solving of students through PBL and conventional learning, 2) know interaction between genders with learning toward increasing skill problem solving of students.

The research hypotheses are 1) increasing of problem solving skill for students received PBL higher than student received conventional loan, 2) there are interaction between genders with learning toward increasing of problem solving skill.

\section{METHOD}

The kind of research was used quasi experiment. Research design, i.e.:

$$
\begin{array}{lll}
\mathrm{O}_{1} & \mathrm{X}_{1} & \mathrm{O}_{2} \\
\mathrm{O}_{1} & & \mathrm{O}_{2}
\end{array}
$$

Both of Experiment class and control were given a pretest and posttest. This research was done in SMP Parayatna Medan.

This variable research is free variable, band variable and control variable. The free variable is learning to use PBL and conventional learning, band variable is problem solving ability and control variable is gender.

These research populations are all of students SMP Prayatna Medan (947 students). The sample used purposive sampling technique. The Class VIII-5 have 36 students as experiment class applying PBL and class VIII-6 have 37 students as a control class applying conventional learning.

Data collection techniques of problem solving ability with gave an essay test to experiment and control groups. The Test forms are pretest and posttest with each 5 problems. The solution of the test was given discordantly. The data is formed during learning group, i.e. PBL or conventional and gender (male and female). Data has formed in group analyzed using of ANAVA statistic two paths with software SPSS 21.0.

\section{RESULT and DISCUSS}

\section{Detail description of problem solving skill}

The data of students' mathematical problem solving abilities in each group are described by calculating the mean and standard deviation. The descriptions of the results can be seen in table 4.1 below:

Table 4.1 Pretest and Posttest Statistic of Problem Solving Ability

\begin{tabular}{lllll}
\hline \multirow{2}{*}{\multicolumn{1}{c}{ Statistic }} & \multicolumn{2}{c}{ Experiment Class } & \multicolumn{2}{c}{ Control Class } \\
\cline { 2 - 5 } & Pretest & Postest & Pretest & Postest \\
\hline Average & 9,194 & 33,194 & 9,081 & 22,622 \\
Standart deviation & 2,875 & 8,787 & 3,096 & 7,434 \\
\hline
\end{tabular}

The Table 4.1 shown that the Average on pre-test result for experiment class and control class are equals, and post-test shown differently because of treatment differs. For experiment class had shown the higher result of post-test of problem solving ability (33.194) than pre-test (9.94) which shown increasing of problem solving ability i.e. 24 . For control class had shown higher post-test result (22.622) than pre-test (9.081) which shown increasing of problem solving ability i.e. 13.541. So the increasing of problem solving ability is higher experiment class than control class.

To know increasing of problem solving ability was used gain index calculation. The result of the calculation was shown in table 4.2. Problem solving ability for the experiment class have a higher average gain index (0.434) than 
the control class (0.243). Counting of average gain index of student problem solving for male and female in the experimental class or control class was shown in figure 4.1

Table 4.2 Gain index statistic of problem solving ability

\begin{tabular}{lcc}
\hline \multicolumn{1}{c}{ Statistik } & Experiment Class & Control Class \\
\hline Average & 0,434 & 0,243 \\
Standart deviation & 0,145 & 0,124 \\
\hline
\end{tabular}

Figure 4.1 Graphic of Problem Solving Ability Based on Gender and Learning

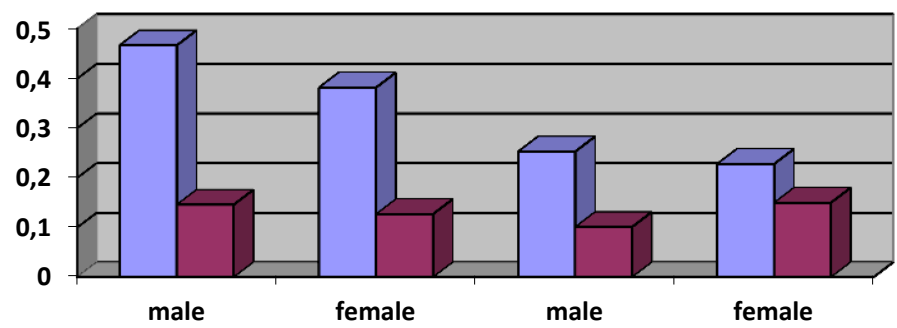

口Average

- Standart Deviation
The Fig 4.1 shown average gain index for male student is higher than female student. It is shown that problem solving ability is higher male than female students in class experiment and also problem solving ability in control class.

\section{Test of Statistical Hypotesis}

Test of hypothesis regulations is normality and homogenity test of data of problem solving ability. Data of normality using Kolmogorov-Smirnov is found significant value 0.105 in experiment class and 0.082 in control class. its means $0.105>0.05$ and $0.082>0.05$, so gain index of problem solving ability both of experiment class and control class are normal distribution. The result of homogenity test of gain index using Levene test is $F_{\text {count }} 3.542$ and Sig. 0.64. $F_{\text {table }(1,71)} 3.978$ whereas significant standard 0,05 for problem solving ability. Its shown that $3.542<3.978$ and $0.64>0.05$. So data of gain index of problem solving ability between experiment class and homogenity control.

The Result of hypothesis test 1 obtained $F_{\text {count }} 32.329$ and sig. $0.00 . F_{\text {table }}$ is 3.982 that $F_{\text {count }}>F_{\text {table }}$ i.e. $32.329>3.982$ and Sig. $<\propto$, ie $0.00<0.05$, so $\mathrm{H}_{0}$ is rejected and $\mathrm{H}_{\mathrm{a}}$ accepted. Thus the improvement of problem-solving abilities of students using problem-based learning is higher than the improvement of problem-solving skills of students using conventional learning.

The Result of hypothesis test 2 obtained $F_{\text {count }} 0,871$ and $\operatorname{Sig} 0,354$. Can be seen from table 4.11 that $\mathrm{F}_{\text {count }}<\mathrm{F}_{\text {table }}$ i.e. $0.871<3.982$ and Sig. $>\propto$ i.e. $0.354>0.05$, so $\mathrm{H}_{0}$ is accepted and $\mathrm{H}_{\mathrm{a}}$ is rejected. Thus it can be stated that there is no interaction between gender and learning to improve problem solving abilities of students. The absence of interaction between gender and learning to improve problem solving skills can also be seen in the figure 4.2, 
Fig 4.2. Interactive Graphic between Gender and Learning toward increasing of problem solving ability of students.

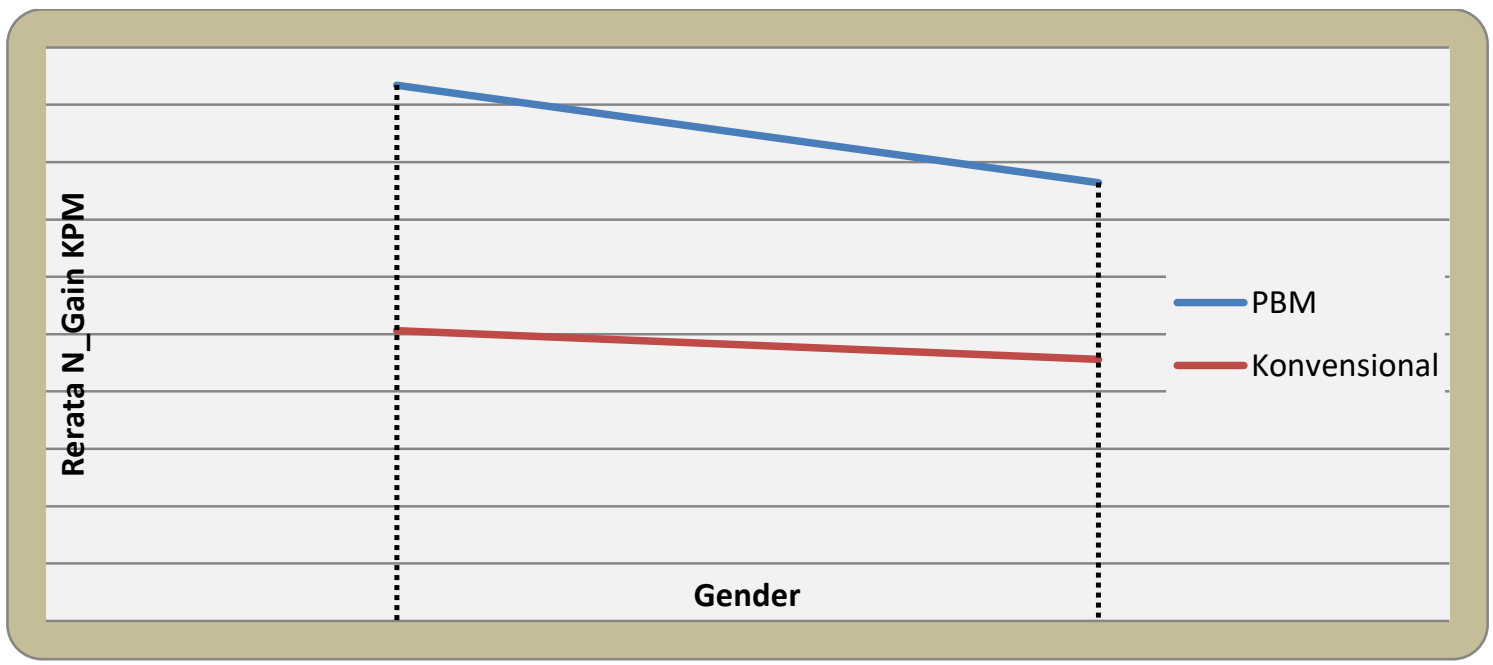

\section{DISCUSS}

There are different of problem solving ability of mathematics of the student because of characteristics from PBL i.e. the problem is recommend, inquiry to solve problems, to give and to show the solution and also collaboration inside solve the problems in group. Vygotsky says learn process will happen if the task was given to students could strengthen and explore of mathematics knowledge of students (Trianto, 2009: 39) and Wahyudin (2008: 27) say equals.

The problem solving, students was given scaffolding so students could solve the problem without favor from other people such as Vygotsky theory about Zone of Proximal Development (ZPD). Treatment of problem solving directly and students solve the various problems whit content of problems, i.e. indicator of problem solving could impact increasing of problem solving ability in mathematics class.

PBL is different with conventional learning. Conventional learning of mathematics materials was shown with structures by the teacher followed the example and exercise of mathematics problems. The problems are not much demand of the think activities to solve problems like analysis, synthesis and evaluation.

Solving of mathematics equations of student only imitates which is explained by a teacher. The Think activities of students in conventional learning class only memorize and understanding process. So when students were given problems, students could not to solve problems of mathematics or problem solving of students still low.

The research result is the interaction between genders with learning toward increasing of problem solving show higher self, value 0.354 than 0.05 which had proven the null hypothesis. Its mean that there is no interaction between gender with learning toward increasing of problem solving. So gender with learning does not give impact on increasing of problem solving ability.

Model of Learning has impact significantly to increase of problem solving ability of students. For so long the learning based on problems contextually, student will involve in activity to solve problems for LKS and students active in the group discuss. Then the activity could impact of increasing of problem solving ability. The other word, differences of increasing of problem solving ability of students is because apply learning not gender.

\section{CONCLUSION AND SUGGESTION}

The class applied PBL have the higher problem solving ability than conventional class and not find interactions on gender with learning toward increasing of problem solving ability. PBL is a model which is suggested in mathematics learning with the purpose to increase problem solving ability, and when 
apply PBL should give a push in the study group, so the activity of problem solving gave impact to increase of mathematics problem solving ability of students.

\section{REFERENCES}

Hannula et al. (2005). Gender Comparisons of Pupils Self-Confidence In Mathematics Learning. Nordic Studies in Mathematics Education No.

3-4, (Online),(http://studentportalen.uu.se /.../download.action?..., diakses 28 Januari 2015).

Hudojo, H. (2005). Pengembangan Kurikulum dan Pembelajaran Matematika. Malang : Universitas Negeri Malang.

Papalia, D. E dan Ruth, D. F.Tanpa tahun. Menyelami Perkembangan Manusia. Terjemahan Oleh : Fitriani W. H. 2014. Jakarta : Salemba Humanika.

Pirnta, S. et al. (2009). Factors Influencing Mathematic Problem-Solving Ability of Sixth Grade Students. Journal of Social Sciences 5 (4): 381-385.

Slavin, R.E. (2006). Psikologi Pendidikan Teori dan Praktik. Terjemahan oleh: Marianto S. 2008. Jakarta: Indeks.

Trianto. (2009). Mendesain Model Pembelajara Inovatif-Progresif : Konsep, Landasan, dan Implementasinya pada Kurikulum Tingkat Satuan Pendidikan. Jakarta : Kencana.

Wahyudin. (2008). Pembelajaran dan Model-Model Pembelajaran. Jakarta: IPA Abong.

Woolfolk, A. Tanpa tahun. Educational Psychology Active Learning Edition Bagian Pertama. Terjemahan Oleh : Soetjipto. 2009. Yogyakarta : Pustaka Pelajar.

Zhu, Z. (2007). Gender differences in mathematical problem solving patterns: A review of literature. International Education Journal, 8(2): 187-203. 